\title{
The fate of DNA of transgenic inulin synthesizing potatoes in pigs
}

\author{
H. Broll ${ }^{1}$, J. Zagon ${ }^{1}$, A. Butschke ${ }^{2}$, A. Leffke ${ }^{1}$, A. Spiegelberg ${ }^{1}$, \\ H. Böhme ${ }^{3}$ and G. Flachowsky ${ }^{3,4}$ \\ ${ }^{1}$ Bundesinstitut für Risikobewertung \\ Thielallee 88-92, 14195 Berlin, Germany \\ ${ }^{2}$ Bundesamt für Verbraucherschutz und Lebensmittelsicherheit \\ Diedersdorfer Weg 1, 12277 Berlin, Germany \\ ${ }^{3}$ Bundesforschungsanstalt für Landwirtschaft (FAL), Institut für Tierernährung \\ Bundesallee 50, 38116 Braunschweig, Germany
}

\begin{abstract}
Silage from a genetically modified potato expressing the 1-SST (sucurose:sucrose 1fructosyltransferase) and the 1-FFT (fructan:fructan 1-fructosyltransferase) was used in a feeding experiment with pigs. After a feeding period of 42 days samples from various organs and digesta were collected and investigated with four different real time PCR systems, in order to identify the fate of the foreign DNA. No plant specific DNA or DNA specific for the genome alteration in the transgenic potato were detected in any organ. In contrast, chloroplast specific DNA was detected in the digesta of duodenum, jejunum, colon and rectum. The single-copy metallo-carboxypeptidase inhibitor gene sequence was detected only in samples from the stomach content of pigs fed the isogenic potato and in those from duodenum and jejunum of animals fed the transgenic one. No evidence for the integration of the foreign DNA into the host genome was observed.
\end{abstract}

KEY WORDS: GMO, pigs, potatoes, PCR

\section{INTRODUCTION}

Horizontal gene transfer, which has been shown to engage members of the same species, of different species, or even of different domains of life, requires a number of steps including uptake of DNA, integration and expression. If the acquired DNA does not provide selective advantage, it is likely to be lost in the population. As a biosafety issue it has been addressed in several studies and a number of potential

\footnotetext{
${ }^{4}$ Corresponding author: e-mail: gerhard.flachowsky@fal.de
} 
hazards has been debated intensively in the scientific as well as the public press (Ho et al., 1999). Gut cells are exposed constantly to DNA fragments deriving from food, and DNA may enter various tissues as shown for maize chloroplast DNA in cattle and chicken after feeding maize (Einspanier et al., 2001).

In this study results will be presented regarding the fate of recombinant DNA derived from genetically modified potatoes fed to domestic pigs.

\section{MATERIAL AND METHODS}

Four pigs were fed for 42 days a silage of a transgenic potato expressing the 1-SST (sucurose:sucrose 1-fructosyltransferase) and the 1-FFT (fructan:fructan 1-fructosyltransferase) (Hellwege et al., 2000). As a control four pigs were fed silage of the parental line. The diets, which were based on cereals and protein concentrates contained $40 \%$ dry matter as potato silage and met the nutrient requirements (Böhme et al., 2005). At the end of the experiment the pigs were slaughtered. From each pig the following samples were taken: blood, tissues from M. longissimus dorsi, glutaeus, thymus glands, spleen, liver, kidney, kidney fat. Digesta samples were collected from stomach, duodenum, jejunum, ileum, caecum, colon and rectum. For DNA extraction from blood the "perfect gDNA blood mini isolation kit" (Eppendorf, Germany) were used according to the manufacturer's instruction. For all other tissue samples the "NucleoSpin Food kit" (Macherey-Nagel, Germany) was used. DNA concentrations were measured using the DyNA Quant ${ }^{\mathrm{TM}} 200$ fluorometer. From bood samples only poor DNA could be extracted around the limit of detection (LOD). From all the other samples DNA concentrations in the range from $20 \mathrm{ng} / \mu \mathrm{l}$ up to more than $300 \mathrm{ng} / \mu \mathrm{l}$ were obtained and adopted to $20 \mathrm{ng} / \mu \mathrm{l}$. For PCR $5 \mu \mathrm{l}$ of the extract (100 ng) was used.

Four different PCR systems were selected for tracing the DNA derived from the transgenic potato. 1. For all tissue samples a PCR system developed by Laube et al. (2003) was selected to determine the integrity and quality of DNA extracted. 2. To identify any inhibition in DNA extracts from the gastrointestinal tract a sequence was selected from the chloroplast genome. The primer/probe system (CPpo2-f/ CP-po2-r/ Cp-Po-Probe) used was originally developed by El Sanhoty (2004). 3. As a singlecopy target sequence of the potato genome, the metallo-carboxypeptidase inhibitor gene DNA sequence was chosen. Primers and probe (PATF/PATR/PATP) were applied according to Hernandez et al. (2001). 4. To identify the genetic modification in the gastrointestinal tract, a real time PCR system has been developed to target the junction between the Cauliflower mosaic virus (CaMV) 35S promoter and the adjacent 1 -sst gene within the genetic construct. By using the specific primers ( $\mathrm{p} 35 \mathrm{~s}-4$ : TCATTTCATTTGGAGAGGACAGG;sst1-rev2: TGGTGAGGGAGG AGTGGG;) a 104 bp fragment is amplified in PCR. 


\section{RESULTS}

In total 110 samples from pigs either fed with transgenic or conventional potatoes were taken and analysed by PCR regarding the fate of the transgenic DNA. As controls in PCR, DNA isolated from the isogenic potato line and DNA from an animal other than the target species were used. From all tissue samples of the organs DNA could be amplified with the myostatine PCR system. This, the DNA extracted from samples was free from inhibition. Using the primers/ probe specific for the chloroplast DNA the PCR was positive, when analysing DNA extracted from gastrointestinal tract samples (data not shown). However, the threshold cycle (CT) values were significantly lower in comparison to the myostatine PCR system using the tissue samples. This was in line with the higher copy number of the chloroplast genome per cell. No significant difference in amplification was observed between the samples from pigs either fed the transgenic or the isogenic potato silage. No tissue sample gave a positive result in PCR with the metallo-carboxypeptidase inhibitor gene real time PCR system or the system specific for the genetic modification in the transgenic potato. The LOD of all real time PCR systems used in this study was determined to be at least 10 genome copies corresponding to approximately 25 pg genomic DNA.

Chloroplast specific DNA was identified by real time PCR in all samples from the different parts of the gastrointestinal tract. However, the amount of DNA detected was below the LOD of the real time PCR system, except for the digesta of jejunum, colon and rectum of the pigs fed isogenic potatoes and of the duodenum, colon and rectum of the pigs fed transgenic potatoes.

For the gastrointestinal tract, using the single-copy metallo-carboxypeptidase inhibitor gene real time PCR system, amplified fragments were only detected, in DNA extract from the stomach content of the pigs fed isogenic potatoes and from the digesta of the duodenum and jejunum in case, the pigs were fed the transgenic ones. No DNA specific for the transgenic DNA could be detected in samples taken from the pigs fed the isogenic potato. When the transgenic potato was fed only the sample from the stomach content was positive in real time PCR. In all PCRs, independent from the system used, the control samples gave the expected results (data not shown).

\section{DISCUSSION}

Two plant-specific real time PCR systems have been applied to tissue samples taken from pigs fed a diet containing silage from genetically modified potatoes or from the respective isogenic line. All samples were negative, although a highly sensitive real time PCR system based on a multi-copy DNA (chloroplast genome) has been chosen. In contrast to the various organ samples, amplified PCR products were 
detected in some of the samples from the digesta either fed the transgenic or isogenic potato line. Because of the high amount of DNA present in the feedstuff, it seems to to make perfect sense that parts of the DNA remain intact as a target molecule for PCR. However, there is no evidence for an integration of DNA into the host genome. Using the PCR systems as described, it is impossible to distinguish between extra chromosomal DNA and DNA integrated into the host genome originating from plant.

\section{REFERENCES}

Böhme H., Hommel B., Flachowsky G., 2005. Nutritional assessment of silage from transgenic inulin synthesizing potatoes for pigs. J. Anim. Feed Sci. 14, Suppl. 1, 335-338

Einspanier R., Klotz A., Kraft J., Aulrich K., Poser R., Schwägele F., Jahreis G., Flachowsky G.., 2001. The fate of forage plant DNA in farm animals: a collaborative case-study investigating cattle and chicken fed recombinant plant material. Eur. Food Res. Technol. 212, 129-134

El Sanhoty R., 2004. Quality control for foods produced by genetic engineering. Dissertation, Technical University Berlin

Hellwege E.M., Czapla S., Jahnke A., Willmitzer L., Heyer A.G., 2000. Transgenic potato (Solanum tuberosum) tubers synthesize the full spectrum of inulin molecules naturally occurring in globe artichoke (Cynara scolymus) roots. Proc. Nat. Acad. Sci. USA 97, 8699-8704

Hernandez M., Ferrando A., Esteve T., Puigdomenech P., Prat S., Pla M., 2003. Real-time and conventional polymerase chain reaction systems based on the metallo-carboxypeptidase inhibitor gene for specific detection and quantification of potato and tomato in processed food. J. Food Protect. 66, 1063-1070

Ho M.W., Ryan A., Cummins J., 1999. Cauliflower mosaic viral promoter - a recipe for disaster? Microbial Ecol. Health Dis. 11, 194-197

Laube I., Spiegelberg A., Butschke A., Zagon J., Schauzu M., Kroh L., Broll H., 2003. Methods for the detection of beef and pork in foods using real-time polymerase chain reaction. Int. J. Food Sci.Technol. 38, 111-18

\section{STRESZCZENIE}

\section{Losy DNA transgenicznej inuliny z ziemniaków po ich podaniu świniom}

Kiszonkę z genetycznie modyfikowanych ziemniaków (o ekspresji 1-fruktozylotransferaza sacharoza:sacharoza (1-SST) oraz 1- fruktozylotransferaza fruktan:fruktan (1-FFT)), jako składnik dawki złożonej ze zboża i koncentratu białkowego, podawano 4 świniom przez 42 dni. Cztery świnie kontrolne otrzymywały kiszonkę ze zwykłych ziemniaków. Stosując metodę real-time PCR nie stwierdzono obecności DNA roślinnego ani DNA transgenicznego w treści pokarmowej dwunastnicy, jelita czczego, okrężnicy i odbytnicy, wykryto natomiast DNA chloroplastów.

Pojedynczą kopię genu inhibitora metalo-karboksypeptydazy wykryto w treści pokarmowej żołądka świń kontrolnych oraz w treści dwunastnicy i jelita czczego świń otrzymujących ziemniaki transgeniczne. 